\title{
Treatment Outcomes of Subureteric Injection and Ureteroneocystostomy in Children with Vesicoureteral Reflux
}

\author{
Serkan Arslan ${ }^{1}$, Mustafa Kucukaydin ${ }^{2}$
}

\begin{abstract}
Objective: This study was designed to evaluate patients treated with subureteric injection (STING) and ureteroneocystostomy by the Lich-Gregoir technique (LGT) due to vesicoureteral reflux (VUR) in terms of radiologic, scintigraphic images, laboratory findings and bladder functions and determine the effectiveness of both treatment modalities.
\end{abstract}

Methods: A total of 106 patients, who were treated with STING and ureteroneocystostomy between January 2002-2010 were investigated. Patients' age, gender, complaints at presentation, bladder function impairment, laboratory outcome and radiologic and scintigraphic findings were retrospectively examined. The relationship among VUR grades and pelvicalyceal ectasia, scars, treatment modalities and outcome were evaluated.

Results: Left VUR was found in 68(64\%) and right VUR in 38(36\%) of the patients. The most common level of VUR was Grade III (42 patients, 40\%). Additional urologic pathologies were found in 60 of the 106 of patients (57\%). Pelvicalyceal ectasia was found in 44 (42\%) and scars were seen in dimercaptosuccinic acid (DMSA) in 54 (51\%) of the patients. In total $86(81 \%)$ of 106 patients with VUR recovered completely and 20 (19\%) patients with VUR regressed.

Conclusion: STING is a good alternative especially for patients with low grade VUR. However, it has some drawbacks, such as requiring a long follow-up period, having a lower rate of success compared to open surgery and being less effective in patients with high grade VUR. Ureteroneocystostomy (LGT) is a method with less morbidity and a high success rate, especially in the treatment of patients with higher grade VUR. J Clin Exp Invest 2016; 7 (2): 168-173

Key words: Children, vesicoureteral reflux, reflux nephropathy, subureteric injection, ureteroneocystostomy

\section{Vezikoüreteral Reflü Bulunan Çocuklarda Subüreterik Enjeksiyon ve Üretero-Neosistostomi Tedavi Sonuçları}

\section{ÖZET}

Amaç: Bu çalışmada; vezikoüreteral reflü (VUR) nedeniyle STING ve Lich-Gregoir yöntemi ile üreteroneosistostomi yapılan hastalar radyolojik, sintigrafik, laboratuar ve mesane fonksiyonları açısından değerlendirilerek her iki tedavi yönteminin etkinliğini belirlemek amaçlanmıştır.

Yöntemler: Ocak 2002-2010 yılları arasında STING ve üreteroneosistomi yapılan toplam 106 hasta değerlendirildi. Hastaların yaşı, cinsiyeti, başvuru yakınmaları, mesane fonksiyon bozukluğu bulguları, laboratuvar değerleri, radyoloji ve sintigrafi bulguları geriye dönük olarak incelendi. VUR dereceleri ile PKE ilişkisine, skar, tedavi yöntemleri ile sonuçları arasındaki ilişki değerlendirildi

Bulgular: Hastaların 68 (\%64) inde Sol VUR inde, 38 (\%36)'inde sağ VUR tespit edildi. En yaygın VUR derecesi Evre III (42 hasta, \%42) VUR idi. 106 hastanın 60'ında (\%57) ek ürolojik patolojiler tespit edildi. Hastaların 54(\%51)'ünde dimercaptosuccinic acid (DMSA)'da skar, 44 (\%42)'ünde pelvikaliksiyel ektazi tespit edildi. Toplamda 106 hastanın 86'sında (\%81) VUR tamamen iyileşirken, 20' sinde (\%19) VUR derecesi geriledi.

Sonuç: STING düşük evreli VUR'da iyi bir seçenektir. Ancak yüksek evreli VUR' larda daha az efektif, açık cerrahiye göre başarı şansı düşük ve uzun dönem takipleri gerektirmesi gibi dezavantajları çalışmamızda görülmüştür. Ureteroneocystostomy (Lich - Gregoir technique) özellikle yüksek evreli VUR lu hastalarında tedavilerinde düşük morbidite ve yüksek başarı oranı olan bir yöntem olduğunu düşünmekteyiz.

Anahtar kelimeler: Çocuklar, vezikoüreteral reflü, reflü nefropatisi, subüreterik enjeksiyon, üreteroneosistostomi, Lich-Gregoir

\footnotetext{
${ }^{1}$ Department of Pediatric Surgery, Medical Faculty of Dicle University, Diyarbakir, Turkey

${ }^{2}$ Department of Pediatric Surgery Medical Faculty of Erciyes University, Kayseri, Turkey
}

Correspondence: Serkan Arslan,

Department of Pediatric Surgery, Medical Faculty of Dicle University, Diyarbakir, Turkey Email: drserkanarslan@hotmail.com Received: 06.03.2016, Accepted: 11.04.2016

Copyright (C) JCEI / Journal of Clinical and Experimental Investigations 2016, All rights reserved 


\section{INTRODUCTION}

Self-amended treatment of VUR is performed either surgically or with endoscopy. In the treatment of VUR, STING is another treatment option. A subureteral dextranomer / hyaluronic acid injection has become the most widely used substance treatment option worldwide in endoscopic therapy [1]. An open surgical procedure can be performed if attempts to treat VUR with injection therapy fail [2].

The most commonly used ureteroneocystostomy techniques are the Politano-Leadbetter, Cohen, and LGT. The aim of surgery is to create a submucosal tunnel which is at least 5 times the size of the ureteral orifice in the bladder. The technique known as the LGT was used by Lich for the first time in 1961, then Gregoir made slight modifications. The most important advantage is the absence of bladder spasm and hematuria as bladder mucosa is not opened. $[3,4]$.

In this study, patients who underwent ureteroneocystostomy with LGT and STING due to VUR are evaluated in terms of radiographic, scintigraphic, laboratory and bladder functions and we aim to determine the effectiveness of each treatment.

\section{METHODS}

In this study, 106 patients who underwent ureteroneocystostomy with STING and LGT due to VUR were evaluated between January 2002 - January 2010 in Erciyes University Faculty of Medicine's Pediatric Surgery Department.

In this study, patients with a mean age of $7.5 \pm$ 4 (0-17 years) who underwent ureteroneocystostomy due to unilateral VUR were evaluated. Bilateral VUR patients, one-sided VUR patients who underwent surgery with other anti-reflux techniques, and patients with chronic renal failure and neurogenic bladder were excluded from the study.

Patients in the $0-17$ years age range (mean age 7.5 \pm 4 years) were divided into 3 groups as $0-12$ months, 13-60 months, and older than 60 months. The relationship among the age groups and presenting symptoms, and accompanying urological pathologies were evaluated. Patients' age, gender, presenting symptoms, bladder dysfunction, signs, laboratory values, radiology, and scintigraphy findings were analyzed retrospectively. The USG PKE relation, scar relationship in DMSA, relationship between the results and treatment methods were evaluated according to grades of VUR.
According to the clinical and laboratory findings, three methods were applied in treatment: medical follow-up, STING and surgical correction. After 6 months, injected patients underwent VUR control with VCUG. Injection and ureteroneocystostomy were applied in unhealed patients. The criteria for treatment success were evaluated as complete disappearance of VUR in control VCUG and decrease to stage I.

The SPSS 15.0 program was used for the statistical analysis of the findings of the study. In the evaluation of the data, average quantitative data were expressed as standard deviation while qualitative data were given as frequencies and percentages. The minimum level of statistical significance was considered as $\mathrm{p}<0.05$.

\section{RESULTS}

Between January 2002 and January 2010, using LGT and STING, 32 male (30\%) and 74 (70\%) female, patients who underwent ureteroneocystostomy due to unilateral VUR were evaluated. The average age of the patients was SD $7.5 \pm 4$ (0-17 years).

When the age and the causes of the patients were evaluated, it was found that patients in the $0-12$ months group applied with complaints of fever, vomiting, anxiety, and urinary tract infection. Patients in the $13-60$ months age group applied mostly due to urinary tract infection (UTI) and patients aged over 60 months applied due to UTI and urinary incontinence (Table 1).

Table 1. Symptoms of patients according to age groups

\begin{tabular}{|c|c|c|c|c|c|c|c|c|c|}
\hline \multirow[t]{2}{*}{ Symptoms } & \multicolumn{2}{|c|}{$\begin{array}{c}0-12 \\
\text { months }\end{array}$} & \multicolumn{2}{|c|}{$\begin{array}{c}13-60 \\
\text { months }\end{array}$} & \multicolumn{2}{|c|}{$\begin{array}{c}>60 \\
\text { months }\end{array}$} & \multicolumn{2}{|c|}{ Total } & \multirow[b]{2}{*}{ p } \\
\hline & $\mathbf{n}$ & $\%$ & $\mathbf{n}$ & $\%$ & $\mathbf{n}$ & $\%$ & $\mathbf{n}$ & $\%$ & \\
\hline UTI & 4 & 50 & 21 & 70 & 44 & 65 & 69 & 65 & NS \\
\hline UI & 0 & 0 & 5 & 48 & 43 & 63 & 48 & 45 & $<0.01$ \\
\hline Fever & 4 & 50 & 9 & 30 & 11 & 16 & 24 & 23 & NS \\
\hline Abdominal ache & 0 & 0 & 5 & 24 & 19 & 28 & 24 & 23 & NS \\
\hline Dysuria & 0 & 0 & 5 & 17 & 12 & 18 & 17 & 16 & NS \\
\hline $\mathrm{IH}$ & 4 & 50 & 6 & 11 & 1 & 1 & 11 & 10 & $<0.01$ \\
\hline Side pain & 0 & 0 & 2 & 11 & 9 & 13 & 11 & 10 & NS \\
\hline Unrest & 5 & 63 & 4 & 10 & 1 & 1 & 10 & 9 & $<0.01$ \\
\hline Vomiting & 4 & 50 & 2 & 9 & 3 & 4 & 9 & 8 & $<0.01$ \\
\hline AP & 0 & 0 & 3 & 5 & 2 & 3 & 5 & 5 & NS \\
\hline Hematuria & 0 & 0 & 0 & 2 & 2 & 3 & 2 & 2 & NS \\
\hline
\end{tabular}

UI: Urinary incontinence, AP: Acute pyelonephritis, UTI: Urinary tract infection, $\mathrm{IH}$ : Intrauterine hydronephrosis, NS: Not significant $(p>0.05)$ 
Of the 106 patients with VUR, grade I-II VUR was detected in 23 patients (21\%), grade III VUR was found in 42 patients (40\%), grade IV VUR in 21 patients (20\%), and grade V VUR in 20 patients (19\%). One hundred and six patients were evaluated in USG examination. The grades of VUR were compared to PKE in USG. PKE was found in $17 \%$ of patients with grade I-II VUR, in $29 \%$ of patients with grade III VUR, in $48 \%$ of patients with grade IV VUR, and in $90 \%$ of patients with grade V VUR. In a total of 106 patients, PKE was found in 44 patients (42\%). In the comparison of grade of VUR and PKE in USG a statistically significant difference was found $(p<0.05)$. The detailed findings are given in (Table 2).

Table 2. Detailed analysis of the patients according to vesicoureteral reflux grades

\begin{tabular}{|c|c|c|c|c|c|c|c|}
\hline & & Grade 1-2 & Grade 3 & Grade 4 & Grade 5 & Total & p \\
\hline Patients, n (\%) & F/M: 74/32 & $23(21)$ & $42(40)$ & $21(20)$ & 20 (19) & 106 & \\
\hline \multirow{2}{*}{ USG, n (\%) } & Normal & $19(83)$ & $30(71)$ & $11(52)$ & $2(10)$ & $62(58)$ & \multirow{2}{*}{$<0.05$} \\
\hline & PKE & $4(17)$ & $12(29)$ & $10(48)$ & $18(90)$ & $44(42)$ & \\
\hline \multirow{2}{*}{ Renal scarring, n (\%) } & Yes & $10(43)$ & $18(43)$ & $10(48)$ & $16(80)$ & $54(51)$ & \multirow{2}{*}{$<0.05$} \\
\hline & No & $13(57)$ & $24(57)$ & $11(52)$ & $4(20)$ & $52(49)$ & \\
\hline \multirow{3}{*}{ STING, n (\%) } & 1 STING & $13(28)$ & $24(51)$ & $6(13)$ & $4(8)$ & $47(44)$ & \multirow{3}{*}{ NS } \\
\hline & 2 STING & $6(30)$ & $9(45)$ & $3(15)$ & $2(10)$ & 20 (19) & \\
\hline & 3 STING & $2(15)$ & $6(46)$ & $4(31)$ & $1(8)$ & $13(12)$ & \\
\hline \multirow{3}{*}{ STING+LGT } & STING & $20(87)$ & $28(67)$ & $8(38)$ & $4(20)$ & $60(57)$ & \multirow{3}{*}{$<0.05$} \\
\hline & STING+ LGT & $13(13)$ & $11(26)$ & $5(24)$ & $3(15)$ & $22(21)$ & \\
\hline & LGT & 0 & $3(7)$ & $8(38)$ & $13(65)$ & $24(23)$ & \\
\hline \multirow{2}{*}{ Treatment outcome } & Improvement & $20(87)$ & $31(74)$ & $17(81)$ & $18(90)$ & $86(81)$ & \multirow{2}{*}{ NS } \\
\hline & Degree of decrease & $3(13)$ & $11(26)$ & 4 (19) & $2(10)$ & 20 (19) & \\
\hline
\end{tabular}

USG: Ultrasonography, PKE: Pelvicalyceal ectasia, LGT: Lich - Gregoir technique, STING: Subureteric injection, F: Female, M: Male, NS: Not significant ( $p>0.05)$

Sixty (57\%) additional urological pathologies were detected in 106 patients with VUR. Among these, DSD (detrusor-sphincter dyssynergia) was found in 23 (22\%), atrophic kidney in 12 (11\%), ureteropelvic (UP) stenosis in $4(4 \%)$, posterior urethral valves (PUV) in $4(4 \%)$, and ureterovesical (UV) stenosis in 4 (4\%) (Table 3).

Table 3. Additional urological abnormalities

\begin{tabular}{lcc}
\hline & $\mathbf{n}$ & $\mathbf{\%}$ \\
\hline Detrusor-sphincter dys-synergia & 23 & 22 \\
Atrophic kidney & 12 & 11 \\
Ureteropelvic obstruction & 4 & 4 \\
Posterior urethral valves & 4 & 4 \\
Ureterovesical obstruction & 4 & 4 \\
Bladder diverticulum & 3 & 3 \\
Ectopic ureter & 2 & 2 \\
Ureterocele & 2 & 2 \\
Labial fusion & 2 & 2 \\
Multicystic dysplastic kidney & 1 & 1 \\
Urinary stone & 1 & 1 \\
Horseshoe kidney & 1 & 1 \\
Simple cysts & 1 & 1 \\
Total & 60 & 57 \\
\hline
\end{tabular}

When the treatment results of patients treated with STING or open surgical treatment were considered, patients outcomes can be summarized as improved VUR grade and decreased VUR grade. Eighty six $(81 \%)$ of 106 patients fully recovered as a result of treatment, and grade of VUR decreased in $20(19 \%)$ of 106 patients (Table 2). Sixty of the 106 patients were treated only by STING, 22 (21\%) by STING and LichGregoir ureteroneocystostomy, and $24(23 \%)$ by only LGT.

UTI in three (4\%), VUR in the other kidney in two $(2 \%)$, temporary obstruction in one $(1 \%)$, and transient side pain in one $(1 \%)$ were detected in 82 patients, who underwent only STING. Of 46 patients who underwent ureteroneocystostomy with LGT, nausea/vomiting in five $(11 \%)$, bladder spasm in three $(6 \%)$, UTI in two patients (4\%), and hydronephrosis in one $(2 \%)$ patient occurred in the early period. In the late period, VUR was detected in the other kidney and was treated with STING (Table 4). 
Table 4. Treatment complications

\begin{tabular}{lccc}
\hline & $\begin{array}{c}\text { STING } \\
\mathbf{n}(\%)\end{array}$ & $\begin{array}{c}\text { LGT } \\
\mathbf{n}(\%)\end{array}$ & $\begin{array}{c}\text { Total } \\
\mathbf{n}(\%)\end{array}$ \\
\hline Nausea and vomiting & 0 & $5(11)$ & $5(11)$ \\
Bladder spasm & 0 & $3(6)$ & $3(6)$ \\
Urinary tract infection & $3(4)$ & $2(4)$ & 0 \\
Contralateral VUR & $2(2)$ & $2(4)$ & 0 \\
Obstruction & $1(1)$ & 0 & $1(1)$ \\
Side pain & $1(1)$ & 0 & $1(1)$ \\
Hydronephrosis & 0 & $1(1)$ & $1(1)$ \\
\hline
\end{tabular}

LGT: Lich - Gregoir technique, STING: Subureteric injection

\section{DISCUSSION}

VUR is the leakage of urine from the bladder to the upper urinary tract. The purpose of UTI treatment is to prevent renal parenchymal damage and other complications of VUR. For this reason, endoscopic and open surgical procedures are performed in the medical treatment of VUR. The LGT is an open surgery technique which is frequently used in patients with unilateral VUR $[1,2]$. In this study, all patients who underwent open surgery were operated on by LGT.

In patients with recurrent UTI, VUR was detected at a ratio of $38 \%$ by Alon et al. [5], at $39 \%$ by Hoberman et al., and at $31 \%$ by McKerrow et al. [7]. In this study, 69 patients with VUR $(65 \%)$ were treated due to UTI. As a result of the low socio-economic levels of patients, lack of follow-up and treatment and poor hygiene, UTI was found to be higher than in the literature.

Although VUR may be an isolated anomaly (primary VUR), it may also occur along with other congenital anomalies (secondary VUR) [8,9]. VUR has been reported with many additional abnormalities. Multicystic dysplastic kidney, renal agenesis, and renal ectopia are the most frequently reported [10]. In the study of Öksüz [11], VUR was detected in 72 of 140 patients $(51 \%)$, and it was reported together with additional urological pathologies. In this study 60 (57\%) additional urologic pathologies were identified among 106 patients. DSD, in this study, was one of the most frequently detected pathologies in patients with VUR. Thus, DSD should be investigated in patients with voiding dysfunction and VUR.

It has been stated in recent studies that VUR occurs as a result of an underlying abnormality [12]. Reducing grade of VUR and the treatment of reflux are more difficult in patients with bladder dysfunction [13]. Soygur et al. [14], by means of urodynamic evaluation, detected voiding dysfunction in $73 \%$ of patients with bilateral VUR. In the literature, in patients with VUR and bladder dysfunction, overactive bladder, neurogenic bladder, and DSD were the most common disorders of bladder function [13]. In the study by Mayo et al. [15], VUR was detected in $50 \%$ of 30 children with DSD detected in urodynamic evaluation. In this study, 70 of 82 patients ( $85 \%$ ) who were toilet trained underwent EMG uroflow and DSD was detected in 23 of them (33\%). Evaluation of accompanying unstable bladder was not carried out for patients who did not undergo routine urodynamics. Ureteroneocystostomy was applied with LGT in 14 of 23 patients with DSD (61\%); six of them (26\%) were given more than one injection. DSD was shown to reduce the success of treatment of VUR in our study.

It is important to perform imaging studies for the detection of VUR in children in high-risk groups. To detect VUR with USG, a sufficient amount of urine is required to puff up the renal pelvis. It is not very reliable in grade I, II, and III VUR where USG with ureteropelvic dilatation is not possible [16]. However with USG, only a high degree of reflux can be detected. Salih and Haberlik [17], in two separate studies, detected a $90 \%$ success rate in grade I,II, and a $100 \%$ success rate in grade III VUR. In the study by Uner et al. [18], 120 ureters in VUR patients were evaluated, and PKE was detected in USG In this study, the grade of VUR of patients were compared with PKE in USG. PKE was detected in $4(17 \%)$ patients with grade I-II VUR, in 12 (29\%) patients with grade III VUR, in 10 (48\%) patients with grade IV VUR, and in $18(90 \%)$ patients with grade V VUR. PKE was detected in 44 $(42 \%)$ of 106 patients $(p<0.05)$. The VUR grades and USG findings are consistent with those in the literature. USG is beneficial as VUR grade increases; therefore we suggest that VUR must be investigated in patients in whom PKE is detected.

The importance of the relationship among UTI, VUR and renal scarring is known. One third of children, surveyed because of UTI had VUR. One third of patients with VUR had kidney damage [19]. Lee et al. [20], when they retrospectively analyzed the records of 220 children under the age of 2 who experienced UTI for the first time, detected renal damage disorder in low grade VUR (I-II) at 38\%, and in high grade (III, IV, V) VUR at $88 \%$. They suggested that there is a direct relationship between grade of VUR and kid- 
ney damage. In another study, It was reported that the grade of VUR is directly associated with renal scarring [14]. There are a number of studies indicating a proportional relationship between renal parenchymal damage and grade of VUR [22]. In this study, scarring was detected in $10(43 \%)$ patients with grade I-II VUR, 18 (43\%) patients with grade III VUR, 10 (48\%) patients with grade IV VUR, and in $16(80 \%)$ patients with grade V VUR. It was found that there is a statistically significant relationship between grade of VUR and scarring $(\mathrm{p}<0.05)$. Macedo et al. [23], in their examination of 45 patients with VUR, found scarring in 32 patients $(71 \%)$. In this study, renal scarring was detected in 54 of 106 patients $(51 \%)$. The reason for the high detection of renal scarring in some degrees of reflux according to the literature is considered to be due to the fact that complicated cases are referred to hospitals with more advanced facilities.

Conservative treatment approaches in the treatment of VUR have steadily gained popularity. However, antireflux surgery remains important. Also, endoscopic methods, especially in the treatment of low grade of VUR, have been suggested as an alternative to open surgery [24-26]. Capozza and Caione [24], published a report indicating the success rate of injection as $95 \%$ in patients with grade II VUR, $71 \%$ in patients with grade III VUR, and $43 \%$ in patients with grade IV VUR.

Similarly, Capozza et al. [24], in their study, reported a success rate of $87 \%$ in patients with grade II VUR, of $75 \%$ in patients with grade III VUR, and of $41 \%$ in patients with grade IV VUR. In the study by Lackgren et al. [25], a success rate of $78 \%$ was achieved in patients with grade II-III VUR, and of $66 \%$ in patients with grade IV VUR. Although endoscopic administration was performed at patients of low-grade VUR in our study due to the UTI and development of renal scarring although antibiotic prophylaxis. Currently conservative treatment is based on the understanding that VUR can resolve spontaneously, mostly in young patients with low-grade reflux. Resolution is approximately $80 \%$ in VUR grade I-II and $30-50 \%$ in VUR grade III-V within 4-5 yr of follow-up. Spontaneous resolution is low for bilateral high-grade reflux [26,27].

In this study, as a result of administering STING 1-3 times, the grade of VUR decreased or fully recovered in $20(87 \%)$ patients with grade I-II VUR, in $28(67 \%)$ patients with grade III VUR, in $8(38 \%)$ patients with grade IV VUR, and in $4(20 \%)$ patients with grade V VUR, Patients who did not heal with STING healed completely with ureteroneocystostomy using LGT. Most of the patients with grade V VUR directly underwent open surgery. A statistically significant difference was found between the treatment results of patients and grade of VUR $(p<0.05)$. The STING treatment success rates in patients conform with literature data. The success of STING treatment varies according to the injection material applied, and to the technique and experience of the surgeon. Therefore different results have been reported in the literature. Subureteric injection was performed under 1 year of age in patients which UTI and development of renal scarring although antibiotic prophylaxis.

In their study, Karakurt et al. [28] reviewed 109 patients who underwent injection and ureteroneocystostomy 1-4 times. The total success rate was founded to be $83 \%$. In this study, among the patients who had 1-3 injections and ureteroneocystostomy by LGT, 20 (87\%) patients with grade I-II VUR, 31 (74\%) patients with grade III VUR, 17 (81\%) patients with grade IV VUR, 18 (90\%) patients with grade V VUR and 86 (81\%) patients of 106 in total recovered completely and in $20(19 \%)$ patients grade of VUR decreased.

In conclusion, it was observed that in patients with grade I, II, and III VUR, if there is no additional urological malformation, treatment with the STING method has a high success rate. It was detected that in patients with grade IV and V VUR, the success rate of the STING method is lower and treatment with ureteroneocystostomy is higher. It was determined that in those who underwent ureteroneocystostomy by LGT, especially on its own, VUR surgical treatment is an effective option which has minimal morbidity and a high success rate. It was determined that in VUR patients with DSD, the success rate rises in VUR treatment when it is combined with DSD treatment.

\section{Acknowledgement}

Financial Disclosure: This study was supported by the Scientific Research and Project Coordinator (TSU-10-3240) in Erciyes University.

Declaration of Conflicting Interests: The authors declare that they have no conflict of interest.

- Ethical approval: The study was approved by the Ethics Committee of the Medical Faculty of Erciyes University

- This study was published as a working thesis in the year 2011 in Kayseri 


\section{- Authors contributions}

SA, MK: Performed the surgery and followed up the patients. They were responsible for the literature review, design, and writing of the manuscript.

MG: Data collection and/or processing

All the authors read and approved the manuscript.

\section{REFERENCES}

1. Tarcan T, Akbal C, Tavukçu HH, et al. The cost-effectiveness of endoscopic treatment and open surgery in the management of vesicoureteral reflux. Pediatr Urol 2007;33:86-91.

2. Greenbaum LA, Mesrobian HG. Vesicoureteral reflux. Pediatr Clin North Am 2006;53:413-27.

3. Jask SE. Vezikoüreteral reflüde cerrahi tedavi. In: Puri P, Hollwarth M, (Cev: Başaklar AC) (eds), Cocuk Cerrahisi. Palme Yayıncılık, 2009; Ankara, ss 499-514.

4. Başaklar AC. Vezikoüreteral reflü. In: Başaklar AC (ed). Bebek ve Çocukların Cerrahi ve Ürolojik Hastalıkları. Palme yayınc1lık, 2006; Ankara, ss 1289-333.

5. Alon US, Ganapathy S. Should renal ultrasonography be done routinely in children with first urinary tract infection? Clin Pediatr (Phila) 1999;38:21-5.

6. Hoberman A, Charron M, Hickey RW, et al. Imaging studies after a first febrile urinary tract infection in young children. N Engl J Med 2003;16:195-202.

7. McKerrow W, Davidson-Lamb N, Jones PF. Urinary tract infection in children. Br Med J (Clin Res Ed) 1984;4:299303.

8. Bensman A, Dun and O, Ulinski T. Urinary tract infection. In: Avner ED, Harmon WE, Niaudet P, Yoshikawa N (eds), Pediatric Nephrology (6th ed). Lippincott Williams-Wilkins, Baltimore. 2009; pp 1199-1210.

9. Ander H, Şanlı Ö. Vezikoüreteral reflü ve megaüreter. In: Anafarta K, Yaman Ö (eds), Temel Üroloji (3rd ed). Güneş Kitabevi, Ankara, 2005; pp 2053-2016.

10. Williams G, Craig JC. Diagnosis and management of urinary tract infections. In: Geary DF, Schaefer F (eds). Comprehensive Pediatric Nephrology. Mosby, Philadelphia. 2008; pp 539-48.

11. Öksüz M (2009) Üriner sistem enfeksiyonu olan çocuk hastaların retrospektif değerlendirilmesi. Expertise Thesis, Pediatrics Department, Ondokuz Mayis University Faculty of Medicine, Samsun, Turkey.

12. McLorie GA, McKenna PH, Jumper BM, et al. Highgrade vesicoureteral reflux: analysis of observational therapy. J Urol 1990;144:537-40.
13. Homayoon K, Chen JJ, Cummings JM, Steinhardt GF Voiding dysfunction: outcome in infants with congenital vesicoureteral reflux. Urology 2005;66:1091-4.

14. Soygür T, Arikan N, Yeşilli C, et al. Relationship among pediatric voiding dysfunction and vesicoureteral reflux and renal scars. Urology 1999;54:905-8.

15. Mayo ME, Burns MW. Urodynamic studies in children who wet. Br J Urol 1990;65:641-5.

16. Claësson I, Jacobsson B, Jodal U, et al. Early detection of nephropathy in childhood urinary tract infection. Acta Radiol Diagn (Stockh) 1981;22:315-20.

17. Salih M, Baltaci S, Kiliç S, et al. Color flow Doppler sonography in the diagnosis of vesicoureteric reflux. Eur Urol 1994;26:93-7.

18. Üner Ç, Yıldız YT, Erdoğan Ö. How much should we rely on ultrasonographic findings in vesicoureteral reflux? Türk Pediatri Arşivi 2003;38:32-35.

19. Cooper CS. Diagnosis and management of vesicoureteral reflux in children. Nat Rev Urol. 2009;6:481-489.

20. Lee HY, Soh BH, Hong CH, et al. The efficacy of ultrasound and dimercaptosuccinic acid scan in predicting vesicoureteral reflux in children below the age of 2 years with their first febrile urinary tract infection. Pediatr Nephrol 2009;24:2009-2013.

21. Tullus K. Vesicoureteric reflux in children. Lancet. 2015;385:371-9.

22. Bellinger MF, Duckett JW. Vesicoureteral reflux: a comparison of non-surgical and surgical management. Contrib Nephrol 1984;39:81-93.

23. Macedo CS, Riyuzo MC, Bastos HD. Renal scars in children with primary vesicoureteral reflux. J Pediatr (Rio J) 2003;79:355-62

24. Capozza N, Lais A, Matarazzo E, et al. Treatment of vesicoureteric reflux: a new algorithm based on parental preference. BJU Int 2003;92:285-288.

25. Läckgren G, Wåhlin N, Sköldenberg E, et al. Long-term follow-up of children treated with dextranomer/hyaluronic acid copolymer for vesicoureteral reflux J Urol 2001;166:1887-92.

26. Tekgül S, Riedmiller H, Hoebeke P, et al. European Association of Urology. EAU guidelines on vesicoureteral reflux in children. Eur Urol 2012;62:534-42.

27. Zambaiti E, Pensabene M, Montano V, et al. Ultrasonographic mound height as predictor of vesicoureteral reflux resolutionafter endoscopic treatment in children. J Pediatr Surg 2016;13:63-6.

28. Karakurt GA, Hakgüder G, Ateş O. Subureteric implant injection in the treatment of vesico-ureteral reflux. Dokuz Eylül Üniversitesi Medical Journal 2009;23:59-64. 